e-ISSN: 2721-3013, p-ISSN: 2721-3005

DOI: https://doi.org/10.38035/jafm.v1i2

Received: 11 April 2020, Revised: 22 April 2020, Publish: 6 May 2020 https://creativecommons.org/licenses/by/4.0/

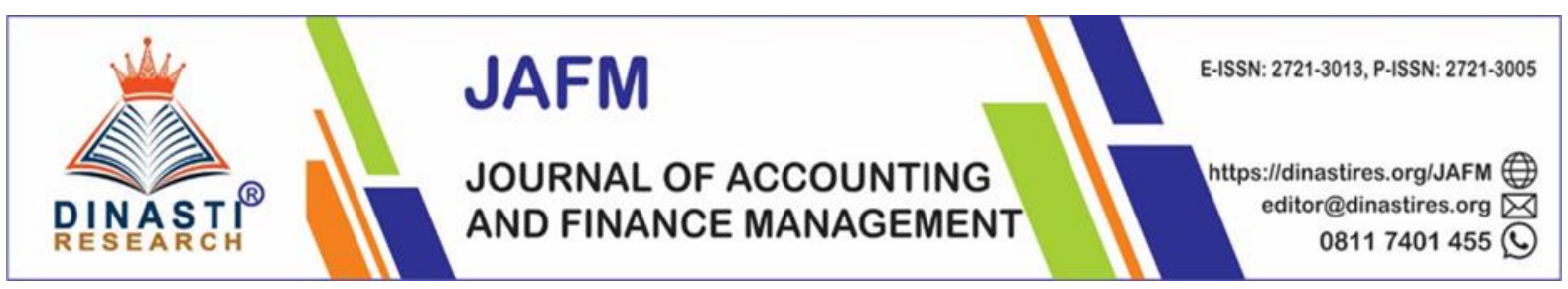

\title{
Event Study of IPO in Indonesia: Pump-and-Dump \& Flipping Strategy Analysis
}

\author{
Eka sudarmaji $^{*}$, Sri Ambarwati ${ }^{2}$, Aulia Keiko Hubbansyah ${ }^{3}$, Shinta Budi Astuti ${ }^{4}$ \\ 1,2,3,4 Fakultas Ekonomi and Bisnis, University of Pancasila, Indoensia, esudarmaji@ univpancasila.ac.id \\ *Corresponding author: Eka sudarmaji ${ }^{1}$
}

\begin{abstract}
There were three important IPO anomalies: the positive average initial return (improperly called short-term 'underpricing'), the long-term underperformance, and hot/cold IPO. The Event Study model explained the 'underpricing' based on the assumption that the underwriter sets the initial price equal to the market-perceived true value and investors were rational. IPO prices are affected by demand and supply. The idea of the model was to explore pump-and-dump and flipping patterns exhibited upon IPO anomalies event in Indonesia. Pump-and-dump is the strategy to manipulate stock prices, while flipping was stocks bought at the IPO and sold at early days ta listing date. This strategy oftentimes exhibits anomalous behavior. Some implications of this model for the IPO market were positive 1st-day initial return (IR) and a negative relation cumulative average abnormal 5-days abnormal return (CAAR-5days) for flipping strategy. The other was a relationship between underperformance cumulative average 30- days abnormal returns (CAAR-30days) and cumulative average 5days (CAAR-5days) abnormal returns in terms of pump-and- dump strategy. Using the relation between the Characteristics (Size of issue, Board and Floating rate) and Macroeconomics Condition (Central Bank Rate, Inflation rate, USD/IDR exchange, and GDP growth), and the IR, a CAAR-5days and a CAAR-30days, this Event Study explained the existence of the pump-and-dump and flipping pattern in the Indonesian stock exchanges. The Authors implemented a multivariate analysis of variance (MANOVA) to test hypotheses regarding the effect of a three-variables dependent (the initial return, a 5- days abnormal return, and a 30-days abnormal return) into several dependent variables. Using the IPO data taken from 2015-2019, the paper found that this Event Study explained the existence of pump-and-dump and flipping patterns at the early trading of IPO stocks in the Indonesia Exchange Market.
\end{abstract}

Keywords: IPO, Pump-and-Dump, Characteristics, Macroeconomic, Abnormal Returns

\section{INTRODUCTION}

The financial fiasco involving two state-owned insurance company, Asabri and Asuransi Jiwasraya, has shocked all the market participants. Jiwasraya and Asabri have been 
alleged as among the perpetrators, buying the small-cap stocks during IPO in collusion with some big investment companies and the stock issuers (www.jakartapost.com). They are been alleged in doing pump-and-dump strategy. Goreng-Saham (frying stocks) or pump-and-dump scams have been identified for more than 41 stocks by The Indonesia Stock Exchange.

Pump-and-dump trading strategy happened due to the manipulative practices adopted by underwriters in the upcoming IPO begins a few weeks in advance before the IPO took place (Aggarwal, Purnanandam, Wu 2004). The pump-organizers in the upcoming IPO consist of an underwriter, consultants, agencies, issuers, promotors, and big investment companies. For this purpose, the issuer usually changes the top management, adding famous directors or commissioners to improve the company reputation and give the appearance of a growing business and solid public image. Pumps and dumps scams in the upcoming IPO consist of a lot of advertising and recommendations of analysts (tend to overconfident) to acquire the IPO shares immediately. The others consist of the issuer company is changing the top management \& put the famous persons on the top. The issuer tends to record its business growth but in the absence of news, having the rumors on the financial results as well as their future contracts without confirmation and lack of information on their financial books. Those pumping were dragging the demand of the stock and push the prices since the beginning of negotiation during the IPO process.

Those false or misinformation were designed to bypass careful analytical reasoning, meaning that it can easily slip under the radar of even the most intelligent and educated people. The goal of these practices is the individual's belief (retail investors). This current situation is being stated as the Era of Post Truth and the Age of Fake News. The reason for this belief is most persons are often well-poised and well-positioned with the leading media outlets since they do provide the latter with much-needed advertising revenues and hence. The mainstream media are unlikely to carry this false information or fake news.

During the IPO process, there are investment banker companies engaged with syndication including stock analysts to guide the company through the IPO process and help them to determine the initial IPO price. The Underwriter Syndicate manages the security offer and it sells to broker-dealers. At the IPO process, stock analysts estimate the valuation price so that the securities demand will reach the expectation. The chosen price will determine the capital that the company will gather by the initial IPO sale. The offering IPO price depends on 1) Company goals, 2) Roadshow Results and 3) Market Conditions. A Company that runs for an IPO needs to show all the best Qualitative Components to get the highest IPO Valuation. But Bradshaw, Richardson \& Sloan, 2003 noted that analysts who are too optimistic and overly confident tend to manipulate the advice given so that it can be said to manipulate the IPO process.

A company that goes public wants long-term investors who hold its stock in the portfolio. Since the opening price tends to become higher than the IPO price, most of the investors are realizing the profit. This Flipping IPO strategy is a common practice that generates trading activity (Ellis et al., 2000, Fishe, 2002). This strategy is also being practiced by long-term investors, especially when they didn't get enough shares during allocation. Their allocation could be too low. So, it doesn't justify the management cost of their investments. When the Flipping happened, the supply of stocks increased then the supply would collapse the price. Besides the institutional investors, the shareowners from the company also can increase the supply. Hence, the underwriter needs to lock some amount of shares for both of them. The purpose of the Lock-up period is to avoid the falling of the price by selling at market opening. The Lock-up period helps to stabilize the stock price.

At the IPO listing date, the IPO stock price will be skyrocketing if the demand relatively high and a lot of people ready to buy it. At the same time, the pump organizer or promotors were taking the opportunity by selling their holdings of the stock, dumping stocks 
into the market and realizing the profit. Those scenarios had made sense for HOT IPOs, but it seems a very rare case lately in Indonesia. Unfortunately, the COLD IPOs didn't get the same condition, At the result, when the interest of the crowd disappears, the stock price will decline upon a few days of trading and retail investors lose their money. Hence the characteristics of pumped IPO can have a quick and large reward only in the short term. The Pump-and-dump trading strategy also exists in the secondary market whose stock prices have been pumping by the news, rumors, and false statements. These pumping schemes occur due to internet technology.

The phenomenon of the IPO will continue to be confusing for most researchers, there is a cycle where the initial IPO return rate is in a positive position (high) and sometimes in a negative position (low). This phenomenon is usually related to the phenomenon of stock listings that are of interest / not interested (Hot / Cold). This IPO initial return rate cycle occurs when some IPO shares jump significantly due to the underpricing phenomenon. However, the movement of IPO shares will then tend to underperform the market in its longterm performance.

Explanation of a simple theoretical model that IPO anomalies generally such as underpricing, long-term underperformance and issuance of shares of interest/not interested (hot issue/cold issue) are based on the assumption that investors are rational, and on average companies or underwriters are not mistaken in IPO stock price valuation. Existing empirical explanations of IPO anomalies are based on ideas or actions taken intentionally (intentional underpricing, price stabilization, etc.) by companies/underwriters that cause irrationality/overreaction from investors. Therefore, this research is to find an explanation of the phenomenon of IPO anomalies in Indonesia by assuming investor irrationality, and with the introduction of post-truth information, the authors want to capture the ideas behind IPO stock anomalies offered in the Indonesia stock market. The general explanation of the anomaly underpricing of IPO shares is based on investors' irrationality and overreaction, unfortunately, it does not provide economic reasons why they fail to behave rationally, and/or why investors consistently always overreact.

\section{LITERATURE REVIEW}

In the 70s and 90s IPO, research was very interesting to many researchers in the US, which was started by Ibbotson and Sindelar (1988), where they documented the positive initial return of IPOs on the US stock market with an average rate of return of $18.80 \%$ to use IPO data 1960-1987. Ibbotson and Ritter (1995) also documented evidence that positive initial returns for IPOs on the US stock market and other international stock markets with an average rate of return varying from $4.2 \%$ to the lowest in French IPOs and the highest to $80.3 \%$ in Malaysia with using IPO data in the 1970s and 1980s. The skyrocketing IPO share price, especially after the first listing in the secondary market, cannot be explained in the movement of stock market theory. The underpricing phenomenon implies that companies get less than what they deserve based on the true value perceived by the market from the company.

On the other hand, Ritter (1991) who used IPO data in 1975-1984 found that IPO shares performed poorly on the stock market after about three financial years. Ritter and Welch (2002) further updated their theory that the phenomenon of IPO shares that occurred, by saying that the phenomenon of IPO shares occurring on IPO shares was not stationary, and the Phenomenon occurred because there were problems with stock allocation, the most common problems found. But they further said that asymmetric information that occurred on IPO shares was not the main driver of the many IPO Phenomena. Instead, they believe further research on future IPO shares will originate revolving around explanations of non-rational conflicts and agency theory. 
In recent years, IPO research has also taken place and has increased with capital market research in developing countries such as China (Chang, Chen, Chi, \& Young, 2008; A. Chen \& Kao, 2006; Mok \& Hui, 1998; Tian, 2011), India (Bansal \& Khanna, 2012; Deb\& Mishra, 2009), New Zealand (Vos \& Cheung, 2018), Bangladesh (Islam, Ali, \& Ahmad, 2010), Indonesia (Manurung \& Manurung, 2019; AH Manurung., E. Juwono \& I. Siswanti, 2019); Indriani \& Marlia, 2013) and many more. The launch of new capital markets IPO products such as REIT and Listed Property Trust (LPT) has also become very popular to be discussed in the IPO Phenomenon literature (Bairagi \& Dimovski, 2011; H. Chen \& Lu, 2006; Dimovski, 2010) and included in the subject of Phenomena flipping action (Bayley, Lee, \& Walter, 2006; Dimovski, 2010).

The phenomenon of the emergence of Bitcoin ICOs and technology startups, together with advances in internet technology, especially social media, have contributed to the manipulation practices that are widely reviewed by researchers. The pump \& dump strategy that is often tinged with manipulation practices is not a new phenomenon. There are many pumps and dump practices that are monitored and recorded by the SEC. The researchers who review this practice include, among others, Riyanto \& Arifin (2018).

\section{Anomali IPO}

A general explanation of the IPO phenomenon can be categorized into three groups: underpricing, overreaction, and other (various) explanations. In general, an underpricingbased explanation states that for some reason the offer price is deliberately set lower by either the company or the underwriter under the actual value perceived by the market per share. In the stock market, the actual price of the stock accurately reflects the actual value perceived by the market per share, therefore the share price in the secondary stock market will be higher than the IPO offering price. As a result, positive initial returns will continue to be in demand by many investors. However, this explanation cannot explain how an anomaly occurs, how the stock performance tends to perform poorly in the long run.

The second group of explanations is an overreaction, that the positive initial return IPO phenomenon can indirectly explain the underpricing anomaly phenomenon. However, the word overreaction and the view that investors are irrational, are very uncomfortable and difficult to explain, especially for most investors with financial backgrounds who believe in the existence of rationality in stock investors. The phenomenon of IPO based on underpricing can explain, that stock prices are made under-compensation for risk so that it will leave a good impression on investors or even indicate how the quality of the company. Ljungqvist (2007) states that four underpricing theories can be grouped, namely: asymmetric information, institutional, control, and behavior. Where the four underpricing theories have implications for the key parties involved in IPO transactions, namely issuing companies, underwriters and marketing agreements, and new investors.

While an overreaction-based IPO can also be explained under the overreaction hypothesis, where underwriters set prices correctly and positive initial returns can be seen as an overreaction from irrational investors in the secondary market. This viewpoint was also investigated by Ritter \& Welch (2002) and Aggarwal (2000), and Aggarwal, Prabhala, and Puri (2002). The concept of overreaction connotes an irrational action/decision making by investors in the secondary market. The argument is mainly based on behavioral and psychological reasons. Supporters of this argument rationalize their view that (i) investors can consistently be irrational / overreact, and (ii) overreaction is only one-way (on positive returns). In contrast to existing hypotheses, this research model is based on the assumption that the underwriter/company averages prices at the actual value perceived by the market per share and all buyers are rational investors. The overall investor reacts correctly.

The IPO stock market which is desirable / not desirable (Hot/Cold) can be explained 
under the macroeconomic hypothesis. The issue of a stock offering that is desirable/not desirable (Hot / Cold) can usually be bound as an indirect implication of explaining the level of excessive positive initial return. Ritter (1991) and Ritter \& Welch (2002) use the winner's curse model, which indicates that there is a positive relationship between uncertainty and underpricing, their hypothesis predicts that the IPO market during the highly desirable stock period consists of offering shares of companies with high risk. Ritter claims that he found evidence of this problem because the relationship between risk and return on positive initial returns is not linear and stationary.

\section{RESEARCH METHODS}

The scope of this research is to investigate the causal relationship between characteristics (Size, Board, Floating, interest/not interest, etc.); Macroeconomic conditions (Central Bank Rate, Inflation rate, USD / IDR exchange, and GDP growth) and positive initial return on IPO shares in Indonesia. Data was taken from 2015-2019, which was obtained from the Indonesia Stock Exchange (IDX) and the Central Statistics Bureau (BPS). The author tries to build a model based on Multivariate Analysis of Variance (MANOVA) is used to estimate and to see the relationship of three dependent variables - the initial return (IR), a CAAR 5dasy abnormal return and a CAAR-30days which are used at the same time to be able to test and see the effect of the relationship with some independent variables originating from endogenous variables and those that come from external or exogenous.

A stock index or composite index samples are taken from companies listed on the Indonesia Stock Exchange. There is 181 number of companies that have conducted IPOs obtained from the Indonesia Stock Exchange, which consists of the Main Board and Emerging Board during the period January 2015 - December 2019. The authors select several macroeconomic and financial variables as two naturally different variables. The econometric methodology is used to test the AR $=0$ hypothesis for each IPO share that has been listed on the IDX Then the authors combine the results of returns throughout the company, which are calculated using average abnormal returns: AARt $=(1 / \mathrm{N}) \Sigma \mathrm{i}$ ARi,t and average abnormal return used $\mathrm{AR}_{\mathrm{jt}}=\mathrm{AR}_{\mathrm{jt}}-\mathrm{R}_{\mathrm{j}}$. For $\mathrm{CAR}$ or Combining Abnormal Return of several companies, the formula used (AAR) Average abnormal return or and cumulative average abnormal return $(\mathrm{CAAR})$ or. $C A A R=\sum A A R_{j t}$ Meanwhile, the Initial Return (IR) calculation on the first day of listing uses IR $=\left(\operatorname{LnR}_{\mathrm{ij}} / \operatorname{LnR}_{\mathrm{ijt}-1}\right)$. IPOs with excessive or highly demanded demand will get a positive average positive initial return, while an IPO with excess supply will experience a negative initial return or an initial negative return. A good proxy for excess demand is the level of excess demand and trading volume in the secondary market; the greater the excess demand, the greater the total shares bought and sold immediately on the secondary market. Previous literature shows that macroeconomic factors and the frequency of IPOs are all in a relationship. Therefore, we present the following hypotheses that we want to test, as follows:

H1: There is a relationship between endogenous factors or 'Characteristics' of the company and / or exogenous factors or 'Macroeconomics' with the IPO with the demand for excess IPO shares. IPOs with excess demand have a positive initial average return and tend to have negative long-term abnormal performance, resulting in a 'pump-and-dump' trend.

$\mathrm{H} 2$ : There is a relationship between either endogenous factors or 'Characteristics' of the company and / or exogenous factors or 'Macroeconomics' with the Hot IPO (cold). IPO hot issues (cold) are characterized by excess demand above the average, thus encouraging these stock investors to do the 'Flipping' strategy. 


\section{RESULTS AND DISCUSSION}

There are 181 companies listed on the mainboard and development board from 2015 to 2019. The amount of funds that can be taken is 129.51 trillion rupiahs with 266.41 million shares during this period, see table. 1 below.

Table 1. Number of IPO Companies, Acquisition Fund and Number of Shares

\begin{tabular}{lcccccc}
\hline \multicolumn{1}{c}{ Description } & $\mathbf{2 0 1 5}$ & $\mathbf{2 0 1 6}$ & $\mathbf{2 0 1 7}$ & $\mathbf{2 0 1 8}$ & $\mathbf{2 0 1 9}$ & Total \\
\hline IPO Fund (Bio IDR) & $7,324.6$ & $11,424.7$ & $34,318.8$ & $61,657.2$ & $14,786.6$ & $129,511.9$ \\
\hline Float (Million) shares & $23,950.1$ & $24,817.5$ & $9,439.0$ & $168,454.0$ & $39,745.5$ & $266,406.1$ \\
\hline Companies & 17 & 15 & 36 & 58 & 55 & 181 \\
\hline
\end{tabular}

In table 2 below, the descriptive statistical test results on the IR, CAAR5-days and CAAR30-days values show an average of $0.326,0.546$ and 0.385 with the data distribution having a maximum value of 2.60 and a minimum of $-1.80,-0.08$ and -0.08 with standard deviations show between 0.0291, 0.0417 and 0.0432 for IR, CAAR 5-days and CAAR30days. From these data, it can be concluded that the average CAAR5-days value or cumulative abnormal return value for all IPO shares is higher than IR and CAAR-30days. While the practice of underpricing in IPO shares cannot be said that is often done on the Indonesian stock exchange given the lowest minimum value occurs in the IR variable while seeing the highest maximum lies in the CAAR-30dyas as a result of the practice of Buy \& Hold still held by investors.

Table 2. Descriptive Statistic

\begin{tabular}{|c|c|c|c|c|c|c|}
\hline \multirow[t]{2}{*}{ DESCRIPTION } & \multirow{2}{*}{$\begin{array}{c}\mathrm{N} \\
\text { Statistic }\end{array}$} & \multirow{2}{*}{$\begin{array}{l}\text { Minimum } \\
\text { Statistic } \\
\end{array}$} & \multirow{2}{*}{$\begin{array}{l}\text { Maximum } \\
\text { Statistic } \\
\end{array}$} & \multicolumn{2}{|c|}{ Mean } & \multirow{2}{*}{$\begin{array}{c}\begin{array}{c}\text { Std. } \\
\text { Deviation }\end{array} \\
\text { Statistic } \\
\end{array}$} \\
\hline & & & & Statistic & Std. Error & \\
\hline 1st Initial Return & 181 & -1.8 & 1.7 & .326 & .0291 & .3910 \\
\hline CAAR-5Days & 181 & -.8 & 2.1 & .546 & .0417 & .5616 \\
\hline CAAR-30Days & 181 & -.8 & 2.6 & .385 & .0432 & .5809 \\
\hline
\end{tabular}

Overall it can be said that the investment of IPO shares in the Indonesian stock exchange in 2015-2019, can be said to have a relatively positive IR, CAAR5days and CAAR30days. This can be seen from graph 1, the distribution of IR values, CAAR-5days and CAAR30-days which are mostly located in positive regions.

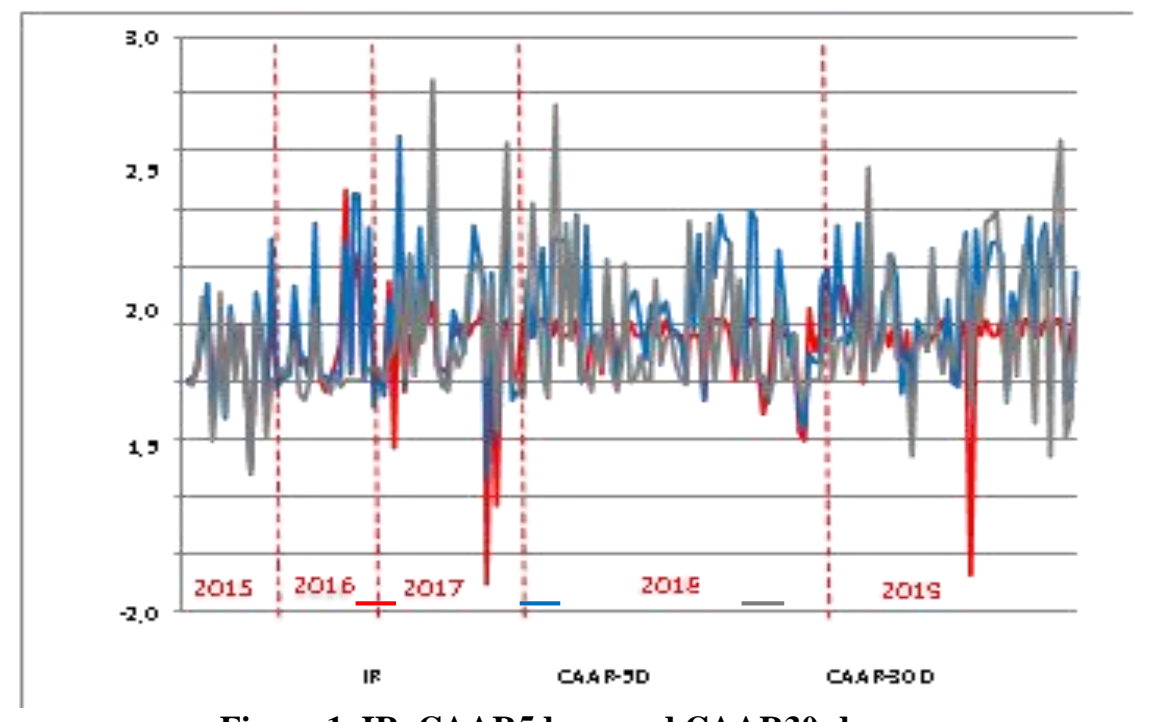

Figure 1. IR, CAAR5days, and CAAR30-days

Bayley, Lee \& Walter (2006) found that flipping took place in the first three days of 
seasoning upon the IPO listing date in the Australian markets. Flipping was also recorded in the US and China. The research also identified the positive and negative aspects of the flipping strategy. The positives were stated as Flipping creates aftermarket trading profits \& liquidity, decreases the cost of trading, lower the issuing firm's cost of capital, and maximizing profit underwriters (Ellis et al., 2000, Fishe, 2002). Authors recognized Flipping in the Indonesian market is using the first five days instead of three days of seasoning trading upon the IPO listing date. Hence five-days cumulative average abnormal return (CAAR5days) less than Initial Return (IR). In formulating a strategy that occurs Pump-and-Dump or not, the authors formulate a pump-and-dump strategy that occurs CAAR-30days compilation is smaller than CAAR-5days, in which the investor takes the position of HOLD positioning and deviates in a relatively long time. compilation of CAAR -30days is greater than CAAR 5 days. This argument builds on the results of research (Komenkul, Sherif \& Xu, 2016) which record the turnover of lists on speculative stocks and underpricing, Ellul and Pagano (2006), Li, Zheng, and Melancon (2005), Zheng, Ogden, and Jen (2005).

Table 3. Flipping, Pump-and-Dump and Under pricing Events

\begin{tabular}{|c|c|c|c|c|c|c|c|c|c|c|}
\hline & \multicolumn{5}{|c|}{ Year } & \multirow[b]{2}{*}{ Total } & \multirow[b]{2}{*}{$\%$} & \multicolumn{2}{|c|}{ Trading board } \\
\hline & & 2015 & 2016 & 2017 & 2018 & 2019 & & & Main & Dev. \\
\hline \multicolumn{2}{|c|}{ UNDERPRICIN Over-Pricing } & 4 & 1 & 7 & 5 & 5 & 22 & $12.2 \%$ & 5 & 17 \\
\hline \multicolumn{2}{|c|}{ GEVENT Unde-Pricing } & 13 & 14 & 29 & 53 & 50 & 159 & $87.8 \%$ & 38 & 121 \\
\hline \multicolumn{2}{|l|}{ Total } & 17 & 15 & 36 & 58 & 55 & 181 & & 43 & 138 \\
\hline \multirow{2}{*}{$\begin{array}{l}\text { PUMP AND- } \\
\text { DUMP EVENT }\end{array}$} & $\begin{array}{l}\text { Long- } \\
\text { Investment }\end{array}$ & 5 & 5 & 16 & 19 & 15 & 60 & $33.1 \%$ & 19 & 41 \\
\hline & $\begin{array}{l}\text { Pump-and- } \\
\text { Dump }\end{array}$ & 12 & 10 & 20 & 39 & 40 & 121 & $66.9 \%$ & 24 & 97 \\
\hline \multicolumn{2}{|l|}{ Total } & 17 & 15 & 36 & 58 & 55 & 181 & & 43 & 138 \\
\hline \multirow{2}{*}{$\begin{array}{l}\text { FLIPPING } \\
\text { EVENT }\end{array}$} & NO FLIP & 6 & 5 & 25 & 40 & 37 & 113 & $62.4 \%$ & 27 & 86 \\
\hline & FLIP & 11 & 10 & 11 & 18 & 18 & 68 & $37.6 \%$ & 16 & 52 \\
\hline \multicolumn{2}{|c|}{ Total } & 17 & 15 & 36 & 58 & 55 & 181 & & 43 & 138 \\
\hline
\end{tabular}

\section{Result of MANOVA}

Based on the Multivariate Analysis of Variance ("MANOVA") analysis, on the multivariate test, the results of the Pillai's Trace test, Wilks' Lambda, Hottelling's Trace \& Roy's largest root are shown in table 4 below, which happened to two groups (Yes or No) The dependent variable Flipping, Pump-and-Dump and Underpricing look significant with the result being 0,000 for the third, at F $(14,160)$, with a P-value that is said to be smaller than $<1 \%$. It can be said that both endogenous and exogenous variables as a whole can influence the dependent variable Flipping and Pump-and-Dump event. The highest PES (partial estimation squared) value is found in the underpricing variable of $53.4 \%$ followed by the flipping and pump-and-dump variables at $37.0 \%$ and $36.3 \%$ statistical values, so it can be stated that the practice of underpricing is mostly done compared to the flipping and pumpand-dump.

Meanwhile, the combination of events or test interactions between the variables Flipping, Pump-and-Dump and Underpricing can occur both together and in pairs. Based on the Pillai's Trace test, Wilks' Lambda, Hottelling's Trace \& Roy's largest root, the value of the Flipping event statistical interaction test which is then followed by a pump-and-dump event has a P-value of 0.003 which is said to be greater than $<1 \%$. Likewise, the statistical interaction test values for the three underpricing events which are then followed by flipping events, underpricing events which are then followed by Flipping and pump-and-dump events, Flipping and Pump-and-Dump together have a P-value of 0.002, 0.000 and 0,000 is said to be smaller than $<1 \%$. The PES (partial estimation squared) value of the highest underpricing and 
pump-and-dump interaction is $21.0 \%$ so that it can be stated that the practice of underpricing will be followed by pump-and-dump practices.

Table 4. Multivariate Tests

\begin{tabular}{|c|c|c|c|c|c|c|c|}
\hline & Effect & Value & $\mathrm{F}$ & $\begin{array}{c}\text { Hypothesis } \\
\text { df }\end{array}$ & Errordf & Sig. & $\begin{array}{c}\text { Partial Eta } \\
\text { Squared }\end{array}$ \\
\hline \multirow[t]{4}{*}{ Intercept } & Pillai's Trace & 1.000 & $8,366,239,965$ & 14 & 160 & - & 1.000 \\
\hline & Wilks' Lambda & 0.000 & $8,366,239,965$ & 14 & 160 & - & 1.000 \\
\hline & Hotelling's Trace & 732,046 & $8,366,239,965$ & 14 & 160 & - & 1.000 \\
\hline & Roy's Largest Root & 732,046 & $8,366,239,965$ & 14 & 160 & - & 1.000 \\
\hline \multirow[t]{4}{*}{ FLIPPING } & Pillai's Trace & 0.370 & 6,704 & 14 & 160 & 0.000 & 0.370 \\
\hline & Wilks' Lambda & 0.630 & 6,704 & 14 & 160 & 0.000 & 0.370 \\
\hline & Hotelling's Trace & 0.587 & 6,704 & 14 & 160 & 0.000 & 0.370 \\
\hline & Roy's Largest Root & 0.587 & 6,704 & 14 & 160 & 0.000 & 0.370 \\
\hline \multirow{4}{*}{$\begin{array}{l}\text { PUMP- } \\
\text { and- } \\
\text { DUMP }\end{array}$} & Pillai's Trace & 0.363 & 6,499 & 14 & 160 & 0.000 & 0.363 \\
\hline & Wilks' Lambda & 0.637 & 6,499 & 14 & 160 & 0.000 & 0.363 \\
\hline & Hotelling's Trace & 0.569 & 6,499 & 14 & 160 & 0.000 & 0.363 \\
\hline & Roy's Largest Root & 0.569 & 6,499 & 14 & 160 & 0.000 & 0.363 \\
\hline \multirow{4}{*}{$\begin{array}{l}\text { UNDERPRI } \\
\text { CING }\end{array}$} & Pillai's Trace & 0.534 & 13,102 & 14 & 160 & 0.000 & 0.534 \\
\hline & Wilks' Lambda & 0.466 & 13,102 & 14 & 160 & 0.000 & 0.534 \\
\hline & Hotelling's Trace & 1.146 & 13,102 & 14 & 160 & 0.000 & 0.534 \\
\hline & Roy's Largest Root & 1.146 & 13,102 & 14 & 160 & 0.000 & 0.534 \\
\hline \multirow{4}{*}{$\begin{array}{l}\text { FLIPPING \& } \\
\text { PUMP- } \\
\text { and- } \\
\text { DUMP }\end{array}$} & Pillai's Trace & 0.182 & 2,539 & 14 & 160 & 0.003 & 0.182 \\
\hline & Wilks' Lambda & 0.818 & 2,539 & 14 & 160 & 0.003 & 0.182 \\
\hline & Hotelling's Trace & 0.222 & 2,539 & 14 & 160 & 0.003 & 0.182 \\
\hline & Roy's Largest Root & 0.222 & 2,539 & 14 & 160 & 0.003 & 0.182 \\
\hline \multirow{4}{*}{$\begin{array}{l}\text { UNDERPRI } \\
\text { CING \& } \\
\text { FLIPPING }\end{array}$} & Pillai's Trace & 0.184 & 2,578 & 14 & 160 & 0.002 & 0.184 \\
\hline & Wilks' Lambda & 0.816 & 2,578 & 14 & 160 & 0.002 & 0.184 \\
\hline & Hotelling's Trace & 0.226 & 2,578 & 14 & 160 & 0.002 & 0.184 \\
\hline & Roy's Largest Root & 0.226 & 2,578 & 14 & 160 & 0.002 & 0.184 \\
\hline \multirow{4}{*}{$\begin{array}{l}\text { UNDERPRI } \\
\text { CING \& } \\
\text { PUMP- } \\
\text { and-DUMP }\end{array}$} & Pillai's Trace & 0.210 & 3,044 & 14 & 160 & 0.000 & 0.210 \\
\hline & Wilks' Lambda & 0.790 & 3,044 & 14 & 160 & 0.000 & 0.210 \\
\hline & Hotelling's Trace & 0.266 & 3,044 & 14 & 160 & 0.000 & 0.210 \\
\hline & Roy's Largest Root & 0.266 & 3,044 & 14 & 160 & 0.000 & 0.210 \\
\hline \multirow{4}{*}{$\begin{array}{l}\text { UNDERPRI } \\
\text { CING \& } \\
\text { FLIPPING } \\
\& \text { PUMP- } \\
\text { and-DUMP }\end{array}$} & Pillai's Trace & 0.207 & 2,990 & 14 & 160 & 0.000 & 0.207 \\
\hline & Wilks' Lambda & 0.793 & 2,990 & 14 & 160 & 0.000 & 0.207 \\
\hline & Hotelling's Trace & 0.262 & 2,990 & 14 & 160 & 0.000 & 0.207 \\
\hline & Roy's Largest Root & 0.262 & 2,990 & 14 & 160 & 0.000 & 0.207 \\
\hline
\end{tabular}

a. Design: Intercept + FLIPPING + PUMP-and-DUMP + UNDERPRICING + FLIPPING \& PUMP-and-DUMP + FLIPPING \& UNDERPRICING + PUMP-and-DUMP \& UNDERPRICING + FLIPPING \& PUMP-andDUMP \& UNDERPRICING

In the error variance test through the Levene's test shown in table 5. Below, the results of this levene test are significant at statistical levels below $5 \%$ for endogenous variables including LnPrice (IDR), Trading Board, Initial Return (IR), CAAR 5-days and 30-days CAAR. Likewise, exogenous variables, SBI rate, BEI average rate, GDP growth, and Inflation rate show a significant statistical level below 5\%. While only two exogenous variables, namely the forex rate, namely Ln-USD / IDR and the overall funds from the IPO results through the Ln-Fund Raise (Billion) proxy, which did not show significant either at the level of $5 \%$ or $10 \%$.

Table 5. Levene's Test of Equality of Error Variances

\begin{tabular}{lcccc}
\hline & F & df1 & df2 & Sig. \\
\hline LnPrice (IDR) & 7.763 & 7 & 173 & 0.000 \\
\hline LnIssue Share (million) & 1.551 & 7 & 173 & 0.153 \\
\hline LnFloat Shares (million) & .682 & 7 & 173 & 0.687 \\
\hline Floating Rate & 1.907 & 7 & 173 & 0.071 \\
\hline
\end{tabular}




\begin{tabular}{lllll}
\hline Initial Return (IR) & 5.821 & 7 & 173 & 0.000 \\
\hline CAAR-5Days & 5.350 & 7 & 173 & 0.000 \\
\hline CAAR-30Days & 5.142 & 7 & 173 & 0.000 \\
\hline SBI- Interest Rate & 2.348 & 7 & 173 & 0.026 \\
\hline BEI Average Return & 2.913 & 7 & 173 & 0.007 \\
\hline Trading Board & 5.121 & 7 & 173 & 0.000 \\
\hline GDP Growth & 4.294 & 7 & 173 & 0.000 \\
\hline Inflation Rate & 2.185 & 7 & 173 & 0.038 \\
\hline Ln USD/IDR & 1.400 & 7 & 173 & 0.208 \\
\hline LnIPO Fund Raise (Billion) & .450 & 7 & 173 & 0.869
\end{tabular}

a. Design: Intercept + FLIPPING + PUMP-and-DUMP + UNDERPRICING + FLIPPING \& PUMP-and-DUMP + FLIPPING \& UNDERPRICING + PUMP-and-DUMP \&

UNDERPRICING +FLIPPING \& PUMP-and-DUMP \& UNDERPRICING

Table 6. Tests of Between-Subjects Effects

\begin{tabular}{|c|c|c|c|c|c|c|c|}
\hline & Source & $\begin{array}{l}\text { Type IIISum of } \\
\text { Squares }\end{array}$ & $\mathrm{df}$ & $\begin{array}{l}\text { Mean } \\
\text { Square }\end{array}$ & $\mathrm{F}$ & Sig. & $\begin{array}{c}\text { Partial Eta } \\
\text { Squared }\end{array}$ \\
\hline \multirow{14}{*}{$\begin{array}{l}\text { Corrected } \\
\text { Model }\end{array}$} & LnPrice (IDR) & $39,929 \mathrm{a}$ & 7 & 6 & 7.842 & 0.000 & 0.241 \\
\hline & LnIssue Share (million) & $17,193 b$ & 7 & 2 & 2.177 & 0.039 & 0.081 \\
\hline & LnFloat Shares (million) & $10,515 \mathrm{c}$ & 7 & 2 & 1.580 & 0.144 & 0.060 \\
\hline & Floating Rate &, $179 \mathrm{~d}$ & 7 & 0 & 1.136 & 0.343 & 0.044 \\
\hline & Initial Return & $14,734 \mathrm{e}$ & 7 & 2 & 28.478 & 0.000 & 0.535 \\
\hline & CAAR-5Days & $35,060 \mathrm{f}$ & 7 & 5 & 39.893 & 0.000 & 0.617 \\
\hline & CAAR-30Days & $37,182 \mathrm{~g}$ & 7 & 5 & 39.023 & 0.000 & 0.612 \\
\hline & SBI- Interest Rate & $0,001 \mathrm{~h}$ & 7 & 0 & 2.222 & 0.035 & 0.082 \\
\hline & BEI Average Return & $1,676 \mathrm{E}-006 \mathrm{i}$ & 7 & 0 & 1.523 & 0.162 & 0.058 \\
\hline & Trading Board & $1,324 \mathrm{j}$ & 7 & 0 & 1.040 & 0.405 & 0.040 \\
\hline & GDP Growth &, $000 \mathrm{k}$ & 7 & 0 & 5.804 & 0.000 & 0.190 \\
\hline & Inflation Rate & $3,255 \mathrm{E}-0051$ & 7 & 0 & 1.242 & 0.282 & 0.048 \\
\hline & Ln USD/IDR & $0,020 \mathrm{~m}$ & 7 & 0 & 1.905 & 0.071 & 0.072 \\
\hline & LnIPO Fund Raise (Bio) & $53,991 \mathrm{n}$ & 7 & 8 & 4.962 & 0.000 & 0.167 \\
\hline \multirow{14}{*}{ FLIPPING } & LnPrice (IDR) & 10.847 & 1 & 11 & 14.912 & 0.000 & 0.079 \\
\hline & LnIssue Share (million) & 0.075 & 1 & 0 & 0.066 & 0.797 & 0.000 \\
\hline & LnFloat Shares (million) & 0.690 & 1 & 1 & 0.726 & 0.395 & 0.004 \\
\hline & Floating Rate & 0.001 & 1 & 0 & 0.050 & 0.823 & 0.000 \\
\hline & Initial Return & 0.192 & 1 & 0 & 2.600 & 0.109 & 0.015 \\
\hline & CAAR-5Days & 3.720 & 1 & 4 & 29.631 & 0.000 & 0.146 \\
\hline & CAAR-30Days & 3.454 & 1 & 3 & 25.375 & 0.000 & 0.128 \\
\hline & SBI- Interest Rate & 0.000 & 1 & 0 & 3.889 & 0.050 & 0.022 \\
\hline & BEI Average Return & 0.000 & 1 & 0 & 1.010 & 0.316 & 0.006 \\
\hline & Trading Board & 0.120 & 1 & 0 & 0.662 & 0.417 & 0.004 \\
\hline & GDP Growth & 0.000 & 1 & 0 & 9.464 & 0.002 & 0.052 \\
\hline & Inflation Rate & 0.000 & 1 & 0 & 0.249 & 0.618 & 0.001 \\
\hline & Ln USD/IDR & 0.001 & 1 & 0 & 0.503 & 0.479 & 0.003 \\
\hline & LnIPO Fund Raise (Bio) & 5.330 & 1 & 5 & 3.428 & 0.066 & 0.019 \\
\hline \multirow{12}{*}{$\begin{array}{l}\text { PUMP-and- } \\
\text { DUMP }\end{array}$} & LnPrice (IDR) & 9.099 & 1 & 9 & 12.508 & 0.001 & 0.067 \\
\hline & LnIssue Share (million) & 0.323 & 1 & 0 & 0.286 & 0.594 & 0.002 \\
\hline & LnFloat Shares (million) & 0.001 & 1 & 0 & 0.001 & 0.971 & 0.000 \\
\hline & Floating Rate & 0.013 & 1 & 0 & 0.574 & 0.450 & 0.003 \\
\hline & Initial Return & 0.124 & 1 & 0 & 1.674 & 0.197 & 0.010 \\
\hline & CAAR-5Days & 0.002 & 1 & 0 & 0.019 & 0.890 & 0.000 \\
\hline & CAAR-30Days & 3.881 & 1 & 4 & 28.516 & 0.000 & 0.142 \\
\hline & SBI- Interest Rate & 0.001 & 1 & 0 & 8.861 & 0.003 & 0.049 \\
\hline & BEI Average Return & 0.000 & 1 & 0 & 7.721 & 0.006 & 0.043 \\
\hline & Trading Board & 0.482 & 1 & 0 & 2.649 & 0.105 & 0.015 \\
\hline & GDP Growth & 0.000 & 1 & 0 & 12.362 & 0.001 & 0.067 \\
\hline & Inflation Rate & 0.000 & 1 & 0 & 1.730 & 0.190 & 0.010 \\
\hline
\end{tabular}




\begin{tabular}{|c|c|c|c|c|c|c|c|}
\hline & Ln USD/IDR & 0.000 & 1 & 0 & 0.004 & 0.950 & 0.000 \\
\hline & LnIPO Fund Raise (Billion) & 9.188 & 1 & 9 & 5.911 & 0.016 & 0.033 \\
\hline \multirow{14}{*}{$\begin{array}{c}\text { UNDERPRICI } \\
\text { NG }\end{array}$} & LnPrice (IDR) & 0.565 & 1 & 1 & 0.777 & 0.379 & 0.004 \\
\hline & LnIssue Share (million) & 2.822 & 1 & 3 & 2.501 & 0.116 & 0.014 \\
\hline & LnFloat Shares (million) & 2.940 & 1 & 3 & 3.093 & 0.080 & 0.018 \\
\hline & Floating Rate & 0.004 & 1 & 0 & 0.193 & 0.661 & 0.001 \\
\hline & Initial Return & 9.395 & 1 & 9 & 127.102 & 0.000 & 0.424 \\
\hline & CAAR-5Days & 9.761 & 1 & 10 & 77.745 & 0.000 & 0.310 \\
\hline & CAAR-30Days & 8.298 & 1 & 8 & 60.963 & 0.000 & 0.261 \\
\hline & SBI- Interest Rate & 0.000 & 1 & 0 & 0.565 & 0.453 & 0.003 \\
\hline & BEI Average Return & 0.000 & 1 & 0 & 0.026 & 0.873 & 0.000 \\
\hline & Trading Board & 0.031 & 1 & 0 & 0.169 & 0.682 & 0.001 \\
\hline & GDP Growth & 0.000 & 1 & 0 & 5.323 & 0.022 & 0.030 \\
\hline & Inflation Rate & 0.000 & 1 & 0 & 3.503 & 0.063 & 0.020 \\
\hline & Ln USD/IDR & 0.004 & 1 & 0 & 2.494 & 0.116 & 0.014 \\
\hline & LnIPO Fund Raise (Billion) & 0.878 & 1 & 1 & 0.565 & 0.453 & 0.003 \\
\hline \multirow{14}{*}{$\begin{array}{l}\text { FLIPPING \& } \\
\text { PUMP- } \\
\text { and-DUMP }\end{array}$} & LnPrice (IDR) & 7.112 & 1 & 7 & 9.777 & 0.002 & 0.053 \\
\hline & LnIssue Share (million) & 2.041 & 1 & 2 & 1.809 & 0.180 & 0.010 \\
\hline & LnFloat Shares (million) & 2.272 & 1 & 2 & 2.390 & 0.124 & 0.014 \\
\hline & Floating Rate & 0.012 & 1 & 0 & 0.521 & 0.471 & 0.003 \\
\hline & Initial Return & 0.109 & 1 & 0 & 1.479 & 0.226 & 0.008 \\
\hline & CAAR-5Days & 0.050 & 1 & 0 & 0.395 & 0.531 & 0.002 \\
\hline & CAAR-30Days & 0.082 & 1 & 0 & 0.601 & 0.439 & 0.003 \\
\hline & SBI- Interest Rate & 0.000 & 1 & 0 & 2.033 & 0.156 & 0.012 \\
\hline & BEI Average Return & 0.000 & 1 & 0 & 1.653 & 0.200 & 0.009 \\
\hline & Trading Board & 0.003 & 1 & 0 & 0.016 & 0.901 & 0.000 \\
\hline & GDP Growth & 0.000 & 1 & 0 & 0.751 & 0.387 & 0.004 \\
\hline & Inflation Rate & 0.000 & 1 & 0 & 0.259 & 0.612 & 0.001 \\
\hline & Ln USD/IDR & 0.000 & 1 & 0 & 0.238 & 0.627 & 0.001 \\
\hline & LnIPO Fund Raise (Billion) & 17.892 & 1 & 18 & 11.510 & 0.001 & 0.062 \\
\hline \multirow{14}{*}{$\begin{array}{c}\text { FLIPPING \& } \\
\text { UNDERPRICI- } \\
\text { NG }\end{array}$} & LnPrice (IDR) & 0.094 & 1 & 0 & 0.130 & 0.719 & 0.001 \\
\hline & LnIssue Share (million) & 1.436 & 1 & 1 & 1.273 & 0.261 & 0.007 \\
\hline & LnFloat Shares (million) & 0.893 & 1 & 1 & 0.940 & 0.334 & 0.005 \\
\hline & Floating Rate & 0.024 & 1 & 0 & 1.066 & 0.303 & 0.006 \\
\hline & Initial Return & 1.497 & 1 & 1 & 20.249 & 0.000 & 0.105 \\
\hline & CAAR-5Days & 2.136 & 1 & 2 & 17.012 & 0.000 & 0.090 \\
\hline & CAAR-30Days & 1.676 & 1 & 2 & 12.311 & 0.001 & 0.066 \\
\hline & SBI- Interest Rate & 0.000 & 1 & 0 & 1.463 & 0.228 & 0.008 \\
\hline & BEI Average Return & 0.000 & 1 & 0 & 1.608 & 0.207 & 0.009 \\
\hline & Trading Board & 0.081 & 1 & 0 & 0.447 & 0.504 & 0.003 \\
\hline & GDP Growth & 0.000 & 1 & 0 & 0.489 & 0.485 & 0.003 \\
\hline & Inflation Rate & 0.000 & 1 & 0 & 0.174 & 0.677 & 0.001 \\
\hline & Ln USD/IDR & 0.002 & 1 & 0 & 1.305 & 0.255 & 0.007 \\
\hline & LnIPO Fund Raise (Billion) & 1.155 & 1 & 1 & 0.743 & 0.390 & 0.004 \\
\hline \multirow{14}{*}{$\begin{array}{c}\text { PUMP-and- } \\
\text { DUMP \& } \\
\text { UNDERPRICI } \\
\text { NG }\end{array}$} & LnPrice (IDR) & 2.481 & 1 & 2 & 3.411 & 0.066 & 0.019 \\
\hline & LnIssue Share (million) & 2.828 & 1 & 3 & 2.506 & 0.115 & 0.014 \\
\hline & LnFloat Shares (million) & 1.970 & 1 & 2 & 2.073 & 0.152 & 0.012 \\
\hline & Floating Rate & 0.009 & 1 & 0 & 0.378 & 0.539 & 0.002 \\
\hline & Initial Return & 0.017 & 1 & 0 & 0.226 & 0.635 & 0.001 \\
\hline & CAAR-5Days & 0.003 & 1 & 0 & 0.027 & 0.870 & 0.000 \\
\hline & CAAR-30Days & 0.309 & 1 & 0 & 2.269 & 0.134 & 0.013 \\
\hline & SBI- Interest Rate & 0.001 & 1 & 0 & 9.362 & 0.003 & 0.051 \\
\hline & BEI Average Return & 0.000 & 1 & 0 & 6.059 & 0.015 & 0.034 \\
\hline & Trading Board & 0.008 & 1 & 0 & 0.044 & 0.833 & 0.000 \\
\hline & GDP Growth & 0.000 & 1 & 0 & 19.830 & 0.000 & 0.103 \\
\hline & Inflation Rate & 0.000 & 1 & 0 & 1.166 & 0.282 & 0.007 \\
\hline & Ln USD/IDR & 0.001 & 1 & 0 & 0.666 & 0.416 & 0.004 \\
\hline & LnIPO Fund Raise (Billion) & 0.010 & 1 & 0 & 0.006 & 0.937 & 0.000 \\
\hline \multirow{4}{*}{$\begin{array}{c}\text { FLIPPING \& } \\
\text { PUMP- } \\
\text { and-DUMP \& } \\
\text { UNDERPRICI }\end{array}$} & LnPrice (IDR) & 1.197 & 1 & 1 & 1.646 & 0.201 & 0.009 \\
\hline & LnIssue Share (million) & 0.047 & 1 & 0 & 0.042 & 0.839 & 0.000 \\
\hline & LnFloat Shares (million) & 0.337 & 1 & 0 & 0.355 & 0.552 & 0.002 \\
\hline & Floating Rate & 0.017 & 1 & 0 & 0.743 & 0.390 & 0.004 \\
\hline
\end{tabular}


NG

\begin{tabular}{lllllll}
\hline Initial Return & 0.452 & 1 & 0 & 6.113 & 0.014 & 0.034 \\
\hline CAAR-5Days & 0.457 & 1 & 0 & 3.638 & 0.058 & 0.021 \\
\hline CAAR-30Days & 1.216 & 1 & 1 & 8.932 & 0.003 & 0.049 \\
\hline SBI- Interest Rate & 0.000 & 1 & 0 & 3.083 & 0.081 & 0.018 \\
\hline BEI Average Return & 0.000 & 1 & 0 & 0.388 & 0.534 & 0.002 \\
\hline Trading Board & 0.233 & 1 & 0 & 1.283 & 0.259 & 0.007 \\
\hline GDP Growth & 0.000 & 1 & 0 & 8.668 & 0.004 & 0.048 \\
\hline Inflation Rate & 0.000 & 1 & 0 & 0.512 & 0.475 & 0.003 \\
\hline Ln USD/IDR & 0.003 & 1 & 0 & 1.883 & 0.172 & 0.011 \\
\hline LnIPO Fund Raise (Billion) & 2.547 & 1 & 3 & 1.638 & 0.202 & 0.009 \\
\hline
\end{tabular}

\section{CONCLUSION}

Some would even argue that pump and dumps should be legal. Pros argue there's always a winner and a loser in the stock market. However, in reality, pump and dump are manipulating the price of a stock by misleading underwriter or pump-organizer. Pump and dump schemes are one of the most important issues especially under Indonesia trading schemes, that showed all amount the dept buy and dept sell in the trading book. Pump and dump will happen with more frequency due to the information on the Internet. Investors failed for IPO frauds and scams for a lot of reasons, gullible and curious, irrational, attracted to gain, uncertain financial environment, etc. Hence, SRO should warn the investors to aware of "pump-and-dump" manipulation in the Indonesian stock exchange. Based on the calculation, the authors deem that is a relationship between endogenous factors or 'Characteristics' of the company and/or exogenous factors or 'Macroeconomics' with the IPO with the demand for excess IPO shares. IPOs with excess demand have a positive initial average return and tend to have negative long-term abnormal performance, resulting in a 'pump-and-dump' trend. On the other hand, IPO hot issues are characterized by excess demand above the average, thus encouraging these stock investors to do the 'Flipping' strategy.

\section{REFERENCE}

Aggarwal, R. (2000). Stabilization Activities by Underwriters After Initial Public Offerings. The Journal of Finance, LV(3), 1075-1103.

Aggarwal, R., Prabhala, N. R., \& Puri, M. (2002). Institutional Allocation in Initial Public Offerings : Empirical Evidence. The Journal of Finance, LVII(3), 1421-1442.

Bairagi, R. K., \& Dimovski, W. (2011). The underpricing of US REIT IPOs : 1996-2010. Journal of Property Research, 28(3), 233-248.

Bansal, R., \& Khanna, D. A. (2012). "Pricing Mechanism and Explaining Underpricing of IPOs": Evidence From Bombay Stock Exchange , India. International Journal of Research in Finance \& Marketing, 2(2), 205-216.

Bayley, L., Lee, P. J., \& Walter, T. S. (2006). IPO Flipping in Australia: Cross-Sectional Explanations. Pacific-Basin Finance Journal, 14, 327-348.

Chang, E., Chen, C., Chi, J., \& Young, M. (2008). IPO Underpricing in China: New Evidence From The Primary And Secondary Markets. Emerging Markets Review, 9, 116.

Chen, A., \& Kao, L. (2006). The Benefit of Excluding Institutional Investors from FixedPrice IPOs : Evidence from Taiwan. Emerging Markets Finance and Trade, 42(5-24).

Chen, H., \& Lu, C. (2006). How Much Do REITs Pay for Their IPOs? Journal of Real Estate Finance Economic, 33, 105-125.

Deb, S. G., \& Mishra, B. (2009). Long-Term Risk-Adjusted Performance of Indian IPOs. Dickey, D. A., \& Fuller, W. A. (1979). Distribution of the Estimators for Autoregressive Time Series With a Unit Root. Journal of the American Statistical 
Association, 74(366), 427.

Dimovski, W. (2010). The Underpricing of A-REIT IPOs in Australia During 2002 to 2008. Pacific Rim Property Research Journal, 16(1), 39-51. https://doi.org/10.1080/14445921.2010.11104294

Ibbotson, R. G., \& Ritter, J. R. (1995). Initial Public Offerings (Vol. 9). Elsevier Science B.V.

Ibbotson, R. G., \& Sindelar, J. I. (1988). OFFERINGS. Journal of Applied Corporate Finance, 1(2), 37-46.

Indriani, S., \& Marlia, S. (2013). The Evidence of IPO Underpricing in Indonesia 2009 2013. Review of Integrative Business \& Economics Research, 4(1), 299-316.

Islam, M. A., Ali, R., \& Ahmad, Z. (2010). Underpricing of IPOs : The Case of Bangladesh. Global Economy and Finance Journal, 3(1), 44-61.

Johansen, S. (1988). Statistical Analysis of Cointegration Vectors. Journal of Economic Dynamics and Control, 12, 231-254.

Ljungqvist, A. (2007). Ipo Underpricing *. In B. E. Eckbo (Ed.), Handbook of Corporate Finance (pp. 376-422). Elsevier B.V.

A. H. Manurung \& J. C. Manurung (2019). Underpricing:Macroeconomic Variables. International Journal of Civil Engineering and Technology (IJCIET), Vol 10, Issue 03, 1739-1745.

A. H. Manurung., E. Juwono \& I. Siswanti (2019). Behavior of Initial Return in Indonesia Market. Journal of Applied Finance \& Banking, vol. 9, no. 4, 2019, 37-45 ISSN: 17926580 (print version), 1792-6599 (online), Scienpress Ltd, 2019.

Mok, H. M. K., \& Hui, Y. V. (1998). Underpricing and Aftermarket Performance of IPOs in Shanghai, China. Pacific Basin Finance Journal, 6, 453-474.

Ritter, J. A. Y. R. (1991). The Long-Run Performance of Initial Public Offerings. The Journal of Finance, XLVI(1), 1-27.

Ritter, J. A. Y. R., \& Welch, I. V. O. (2002). A Review of IPO Activity, Pricing, and Allocations. The Journal of Finance, LVII(4), 1795-1828.

Tian, L. (2011). Regulatory Underpricing: Determinants of Chinese Extreme IPO Returns 㑱. Journal of Empirical Finance, 18(1), 78-90. Retrieved from http://dx.doi.org/10.1016/j.jempfin.2010.10.004

Vos, E. A., \& Cheung, J. (2018). New Zealand IPO Underpricing: The Reputation Factor. Small Enterprise Research, 03(23). 